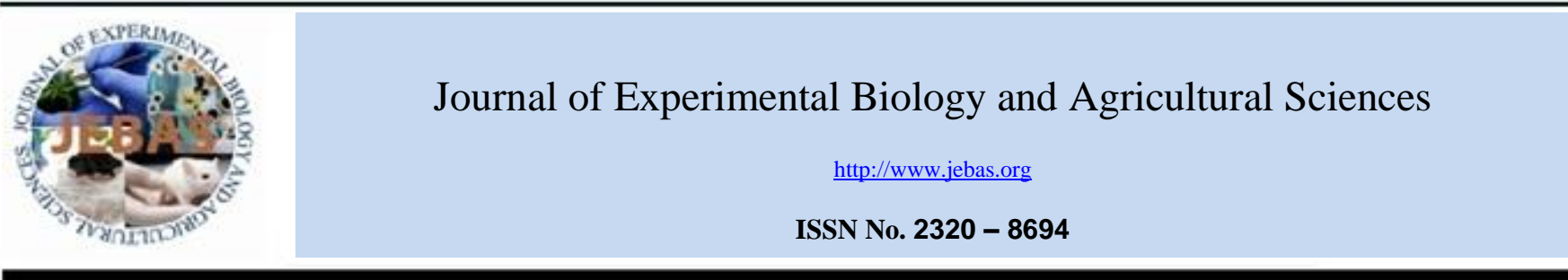

\title{
ASSOCIATION BETWEEN FALLING NUMBER AND GRAIN CHARACTERISTICS TO EVALUATE PREHARVEST SPROUTING IN WHEAT
}

\author{
Okuyama LA ${ }^{1} *$, CR Riede ${ }^{1}$, MM Kohli $^{2}$ \\ ${ }^{1}$ Instituto de Desenvolvimento Rural do Paraná - IAPAR - EMATER, Caixa Postal 10030, CEP 86047-902 Londrina, Paraná, Brazil \\ ${ }^{2}$ Camara Paraguaya de Exportadores y Comercializadores de Cereales y Oleaginosas (Capeco), Av. Brasilia 840, Asunción, Paraguay
}

Received - September 28, 2020; Revision - November 25, 2020; Accepted - December 18, 2020

Available Online - December 30, 2020

DOI: http://dx.doi.org/10.18006/2020.8(6).758.764

\section{KEYWORDS \\ Triticum aestivum \\ Genotypes \\ Germination percentage \\ Visual score \\ Grain quality}

* Corresponding author

E-mail: lauro2288@gmail.com (Lauro Akio Okuyama)

Peer review under responsibility of Journal of Experimental Biology and Agricultural Sciences.

Production and Hosting by Horizon Publisher India [HPI] (http://www.horizonpublisherindia.in/).

All rights reserved.

\begin{abstract}
The falling number $(\mathrm{FN})$ is a widely used parameter to evaluate sprouting damage in wheat. Despite its importance, many breeding programs lack facilities to determine the FN routinely. This study was conducted to elucidate the relationship of the falling number with germination percentage, visual sprouting score, hectoliter weight and the grain weight per spike, to improve the selection criteria in the pre-harvest sprouting (PHS) trials. Thirteen genotypes differing in PHS tolerance were evaluated in a rain simulator. The statistical analysis was conducted to understand the relationship of FN with grain characteristics. The path coefficient analysis revealed the highest association of the FN with the percentage of sprouted grains. Also, regression analysis determined that samples with more than $46 \%$ of sprouted grains had FN below 200s. The grains with 32 to $46 \%$ of germination resulted in FN values between 200 and 250 s, and those with 19 to $32 \%$ of germination had FN between 250 and 300 s. Only those samples with less than $19 \%$ of germination resulted in FN values higher than 300s. The strong association between the germination percentage and the FN allows the selection of promising lines and the elimination of undesirable ones at an early stage of breeding.
\end{abstract}

All the articles published by Journal of Experimental Biology and Agricultural Sciences are licensed under a Creative Commons Attribution-NonCommercial 4.0 International License Based on a work at www.jebas.org. 


\section{Introduction}

The climatic conditions during wheat maturity are an important factor affecting pre-harvest sprouting (PHS) (Paterson et al., 1989). The PHS stimulated by the rain during the wheat harvest is associated with visible grain characteristics, such as swelling, wrinkles, discoloration, seed coat split, and the emergence of radicles (Thomason et al., 2019). On the other hand, the lower temperatures during the grain ripening induce a higher level of dormancy and, therefore, lower damage to the grains (Reddy et al., 1985). Under controlled conditions, PHS damage can be assessed by exposing spikes to artificial rain or through germination tests or by natural/ artificial weathering of the spike etc. It is also feasible to assess indirect damage caused by sprouting through Hagberg falling number (FN) parameter or molecular markers (DePauw et al., 2012), and the use of near-infrared (NIR) hyperspectral imaging (Barbedo et al., 2018). The falling numbers are influenced by the interaction between cultivar and environment and by the $\mathrm{N}$ management (Silva et al., 2019). The genetic expression of PHS resistance (low $\alpha$-amylase activity, high $\mathrm{FN}$ values, maintenance of rheological and cooking properties) can be observed and measured reliably in wet pre-harvest conditions (Dencic et al., 2013). In other words, the level of $\alpha$-amylase activity, which is affected by climatic variations, can be used as a practical parameter to estimate the industrial value of the grain and its bread-making quality (Rakita et al., 2015). It has been shown that higher $\alpha$-amylase activity substantially lowers the quality of the final product resulting in lower price and loss of seed viability during the storage (Mares \& Mrva, 2014). Given the negative relationship between $\alpha$ amylase content and falling number values, this evaluation has been accepted in the international grain trade. Depending on the standard agreed by the wheat industry, FN values above 250 or 300 seconds are generally considered minimum quality grades (Mares \& Mrva, 2008). In the Pacific Northwest region of the United States, a wheat lot with FN below 300 seconds is typically discounted, to promote higher values and compete well in the export market (Steber, 2016). Despite FN being an effective parameter, it is difficult to conduct it on a large number of preliminary genotypes in a wheat-breeding program, especially in developing countries. These difficulties can vary with the lack of equipment, a laboratory, or trained personnel etc., which limit the number of samples to be analyzed in one day. The alternative selection method viz. artificial weathering, allows a rapid evaluation of large number of genotypes and is used for the selection of PHS (MacMaster \& Derera, 1976; Franco et al., 2009, Gavazza et al., 2012, Okuyama et al., 2018). In these studies, different parameters such as visual scoring (MacMaster \& Derera, 1976, Franco et al., 2009); the percentage of sprouted grains ( Bassoi et al., 2006; Franco et al., 2009; Gavazza et al., 2012; Zeeshan et al., 2018), and other characteristics such as grain weight per spike and hectoliter weight (Nörnberg et al., 2015b) have been explored. Although such assessments have been successful to identify genotypes tolerant to PHS, they do not permit to establish their relationship with the FN value of the sample. Thus, the present study was carried out to determine an association between the FN and the grain germination percentage, the visual scores, the grain weight per spike, and the hectoliter weight. We believe that such information can be a useful criterion for the selection, early discard of unsuitable lines, and planning a new cycle of hybridization for resistance to PHS.

\section{Materials and Methods}

Field experiments were carried out at the Instituto de Desenvolvimento Rural do Paraná - IAPAR - EMATER, situated in Londrina, Brazil. The plot size consisted of three rows, two meters long and $30 \mathrm{~cm}$ apart, at a seeding rate of 350 seeds $\mathrm{m}^{-2}$. Thirteen genotypes of wheat, with wide variation for PHS tolerance (High: Frontana, CD 114 and Safira; Intermediate:OR1, CD 116, IPR 136, IPR 128, BRS 220, IPR 85 and CD108; Low:BR 18 , CD 104 and CD 105), were evaluated over two sowing dates in four years. At maturity, approximately 100 spikes per cultivar were harvested manually by following the method given by Heft \& Wych (1982) and kept at room temperature. Twenty spikes per cultivar were inserted in polystyrene trays spaced $5 \mathrm{~cm}$ in the row and $10 \mathrm{~cm}$ between the rows, in four replications. They were exposed to artificial rain (nebulizer) under controlled conditions using the previously described methodology (Okuyama et al., 2018). The nebulizer was scheduled to switch on /off, every 30 minutes, to produce around $280 \mathrm{~mm}$ of mist per day. The tests started around $9 \mathrm{AM}$ and lasted 48 hours, after which, the spikes were sun-dried and threshed manually. The grain germination percentage (sprouting) was evaluated twice, each in a 50-grain sample, using a magnifying glass (10X), to observe the rupture of the pericarp, considered as the start of the germination process (Nyachiro et al., 2002; Bassoi \& Flintham, 2005). The Falling Number tests were performed on a FN 1500 (Perten Instruments), according to the 56-81 B method approved by the American Association of Cereal Chemists (AACC, 2000). The hectoliter weight was determined by the ratio of grain weight to the volume of the container and reported as $\mathrm{kg} / \mathrm{hl}$. Grain germination was scored adopting the methodology proposed by Yanagisawa et al. (2005): 1: no visible germination; 2: low germination (1-20\%); 3: moderate germination (21-40\%); 4. high germination (41-60\%); 5: extremely high germination (60-80\%); 6. complete germination (> 81\%). The grain weight measurement was based on the average of 10 spikes, at $13 \%$ moisture content. The data were transformed to satisfy the assumption of additivity in the following manner: Falling Number (logarithmic transformation); percent of germination (arc sine transformation), visual scoring (square root transformation) was estimated according to Snedecor \&Cochran (1982). The Analysis of variance, the path coefficient procedure, 
the Pearson's correlation coefficient, and the regression analysis was used to determine the relationship between the FN and the grain characteristics by the Genes software (Cruz, 2006a, Cruz, 2006b) and the SAS package (SAS, 2001).

\section{Results and Discussion}

The results demonstrated significant differences among genotypes for all the characteristics under study viz. the FN, germination percentage, visual sprouting score and the hectoliter weight. The combined analysis of variance (anova) revealed that the treatments, including year, block (year), and genotype were highly significant $(\mathrm{P} \leq 0.01$ ), while the interaction hectoliter weight $\mathrm{x}$ block (year) was significant at $\mathrm{P} \leq 0.05$. Given that the interaction year $\mathrm{x}$ genotype was not significant $(\mathrm{P}>0.05)$ for the $\mathrm{FN}$, the germination percentage, the visual sprouting score, the grain weight per spike, and the hectoliter weight, it can be surmised that all genotypes demonstrated a stable performance over the years (Table 1). The results of this study show a high negative association between the $\mathrm{FN}$ and the germination percentage $(\mathrm{r}=-0.9082 * *)$ and between the $\mathrm{FN}$ and the visual sprouting score $(\mathrm{r}=-0.8956 * *)$. A lower magnitude of association $(\mathrm{r}=-0.6403 *)$ was observed between the $\mathrm{FN}$ and the grain weight per spike, while no association was observed between the FN and the hectoliter weight $(r=0.5326 \mathrm{~ns})$ (Table 2). Additionally, the direct and indirect effects of the grain characteristics that influence the falling number were determined by the path coefficient analysis (Table 3). It was observed that the germination percentage was the single most important source of variation in the FN $(\mathrm{r}=-0.9047 * *)$, with a medium negative direct effect (-0.5156). On the other hand, despite a highly significant correlation coefficient $(r=-0.8957 * *)$, the relationship between the visual sprouting score and the FN was not so clear when the path analysis was performed and showed a lower direct effect (-0.1518). It is believed that the high correlation resulted primarily from the high indirect effect of the germination percentage (-0.4569). Both hectoliter weight and grain weight per spike showed a low correlation ( 0.5308 and -0.6432 respectively), as well as a low direct effect ( 0.2181 and -0.3439 respectively) with the FN. Thus, it is safe to conclude that the FN was more affected by the germination percentage than any other grain character studied. Our findings support the results reported by Nörnberg et al. (2015a), in that the percentage of sprouted grains affected negatively the FN in adverse crop environments. It is interesting to observe that the relationship between the $\mathrm{FN}$ and the grain characteristics behaved differently in the path coefficient analysis compared to the simple

Table 1 Analysis of variance for the Falling Number and the grain characteristics of wheat genotypes

\begin{tabular}{|c|c|c|c|c|c|c|}
\hline Source & df & $\begin{array}{l}\text { Falling number } \\
\text { (s) }\end{array}$ & $\begin{array}{c}\text { Germination } \\
(\%)\end{array}$ & $\begin{array}{l}\text { Mean square } \\
\text { Visual scoring } \\
\quad(1 \text { to } 6)\end{array}$ & $\begin{array}{l}\text { Hectoliter weight } \\
(\mathrm{Kg} / \mathrm{hl})\end{array}$ & $\begin{array}{c}\text { Grain spike }{ }^{-1} \\
(\mathrm{~g})\end{array}$ \\
\hline Year & 3 & $0.4514 * *$ & $0.5513 * *$ & $0.3309 * *$ & $70.2685 * *$ & $0.2411 * *$ \\
\hline Block(year) & 4 & $0.1810 * *$ & $0.1537 * *$ & $0.1470 * *$ & $9.9852 *$ & $0.2014 * *$ \\
\hline Genotype & 12 & $0.2335 * *$ & $0.4310 * *$ & $0.4574 * *$ & $16.0577 * *$ & $0.3899 * *$ \\
\hline Year x Genotype & 36 & $0.0153 \mathrm{~ns}$ & $0.0332 \mathrm{~ns}$ & $0.0460 \mathrm{~ns}$ & $5.9201 \mathrm{~ns}$ & $0.0383 \mathrm{~ns}$ \\
\hline Error & 48 & 0.0178 & 0.0315 & 0.029 & 3.5696 & 0.0279 \\
\hline R-Square & & 0.8644 & 0.8510 & 0.8626 & 0.7930 & 0.8500 \\
\hline Coef. Var & & 5.9499 & 24.1512 & 9.4306 & 2.5438 & 12.0833 \\
\hline Root MSE & & 0.1333 & 0.1775 & 0.1701 & 1.8893 & 0.1670 \\
\hline Mean & & 202.05 & 45.69 & 3.36 & 74.27 & 1.38 \\
\hline
\end{tabular}

*, ** Significant at $\mathrm{P}<0.05$ and $\mathrm{P}<0.01$, respectively; ns: Not significant $(\mathrm{P}>0.05)$.

Table 2 Pearson's correlation between Falling Numbers and grain characteristics

\begin{tabular}{|c|cccc|}
\hline Traits & Germination & Visual scoring & Hectoliter weight & Grain spike $^{-1}(\mathrm{~g})$ \\
\hline Falling Number (s) & $-0.9082^{* *}$ & $-0.8956^{* *}$ & $0.5326^{\mathrm{ns}}$ & $-0.6403^{* *}$ \\
\hline Germination (\%) & & $0.8899^{* *}$ & $-0.4583^{\text {ns }}$ & $0.4529^{\text {ns }}$ \\
\hline Visual scoring & & $-0.5910^{*}$ & $0.4554^{\text {ns }}$ \\
\hline Hectoliter weight $(\mathrm{kg} / \mathrm{hl})$ & & & $0.0259^{\mathrm{ns}}$ \\
\hline
\end{tabular}

* Significant at $\mathrm{P} \leq 0.05$; **significant at $\leq 0.01$; ns: Not significant.

Journal of Experimental Biology and Agricultural Sciences

http://www.jebas.org 
correlation analysis. While the correlation analysis established a negative relationship between the $\mathrm{FN}$ and the germination percentage, the visual score, and the grain weight per spike, the path analysis assigned importance only to the first character (germination percentage). Such a discrepancy can be explained by the differences in the two analytical approaches. While the correlation simply identifies the mutual association among the parameters, the path coefficient analysis allows the study of the magnitude of each effect (Dewey \& Lu, 1959), thereby providing a better understanding of the complexities of factors involved in the selection process (Scheiner et al., 2000). The FN test has proven to be the most reliable for determining PHS and $\alpha$-amylase activity (Barnard et al., 2005; Nörnberg et al., 2015a). Yet, the lack of equipment/trained personnel or the difficulty and cost involved to analyze a large number of samples in a breeding program, make it prohibitive as a screening tool. Therefore, many programs use sprouting scores to discard the most susceptible lines (Humphreys \& Noll, 2002) or the germination test to select for PHS resistance (Zeeshan et al., 2018). Artificial weathering tests can also be very useful when high throughput is required, such as in mid-generation selection, where the objective is to screen rather than calibrate (Shorter et al., 2005).

Table 3 Direct and indirect effects of the factors that influence the Falling Number in wheat genotypes submitted to the pre-harvest sprouting test

\begin{tabular}{|c|c|c|c|}
\hline \multirow[b]{2}{*}{ Association } & \multicolumn{3}{|c|}{ Genotype path coefficient } \\
\hline & Direct effect & Indirect effect & Correlation \\
\hline \multicolumn{4}{|l|}{ Falling Number vs. Germination percentage } \\
\hline Direct effect & -0.5156 & & \\
\hline Indirect effect via Visual scoring & & -0.1345 & \\
\hline Indirect effect via Hectoliter weight & & -0.0979 & \\
\hline Indirect effect via Grain weight per spike & & -0.1567 & \\
\hline TOTAL & & & -0.9047 \\
\hline \multicolumn{4}{|l|}{ Falling Number vs. Visual scoring } \\
\hline Direct effect & -0.1518 & & \\
\hline Indirect effect via Germination percentage & & -0.4569 & \\
\hline Indirect effect via Hectoliter weight & & -0.1289 & \\
\hline Indirect effect via Grain weight per spike & & -0.1581 & \\
\hline TOTAL & & & -0.8957 \\
\hline \multicolumn{4}{|l|}{ Falling Number vs. Hectoliter weight } \\
\hline Direct effect & 0.2181 & & \\
\hline Indirect effect via Germination percentage & & 0.2314 & \\
\hline Indirect effect via Visual scoring & & 0.0898 & \\
\hline Indirect effect via Grain weight per spike & & -0.0085 & \\
\hline TOTAL & & & 0.5308 \\
\hline \multicolumn{4}{|l|}{ Falling Number vs. Grain weight per spike } \\
\hline Direct effect & -0.3439 & & \\
\hline Indirect effect via Germination percentage & & -0.2349 & \\
\hline Indirect effect via Visual scoring & & -0.0698 & \\
\hline Indirect effect via Hectoliter weight & & 0.0054 & \\
\hline TOTAL & & & -0.6432 \\
\hline Coefficient of determination & & & 0.9394 \\
\hline Residual & & & 0.2462 \\
\hline
\end{tabular}

Journal of Experimental Biology and Agricultural Sciences

http://www.jebas.org 


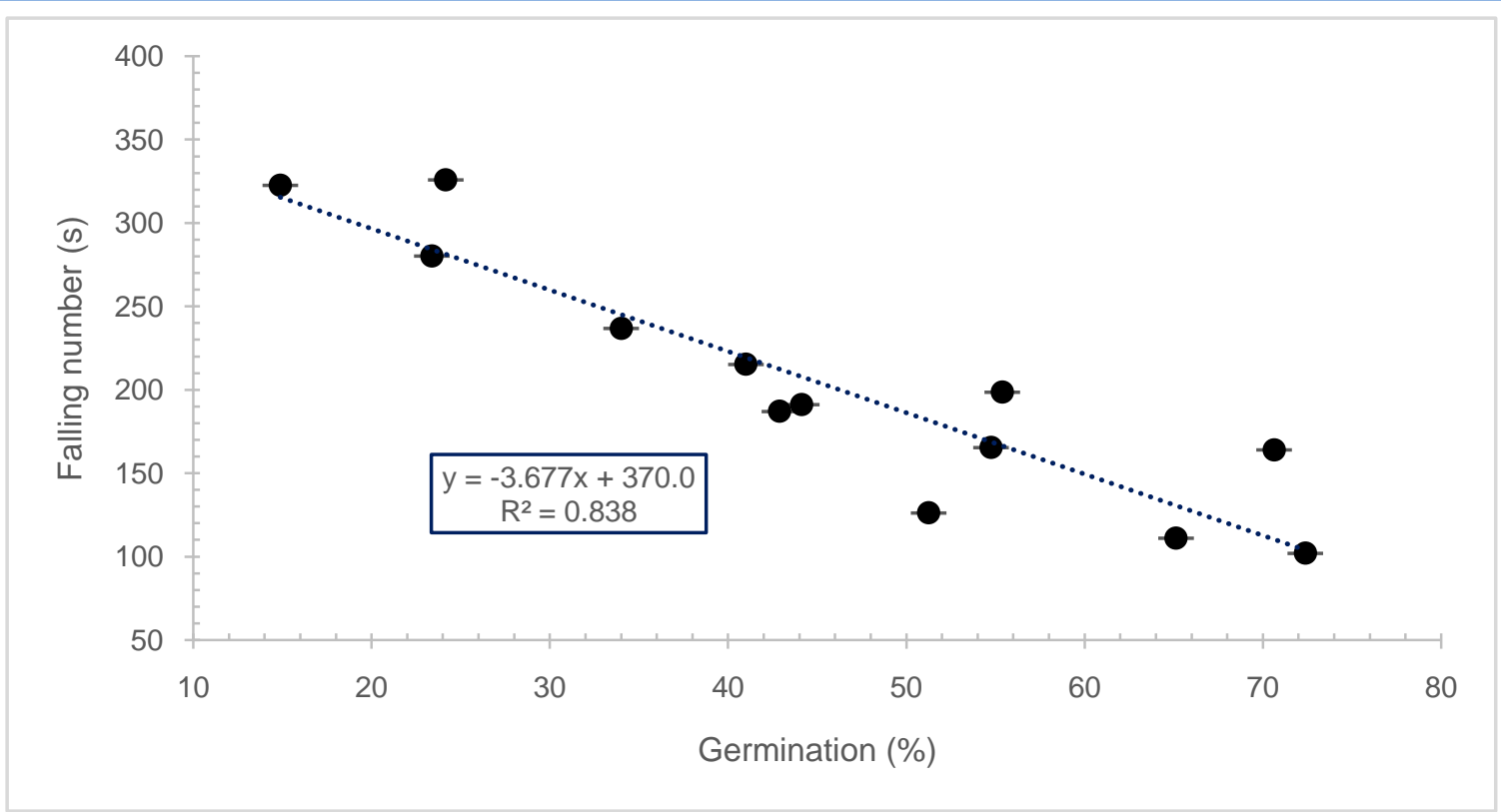

Figure 1 Negative linear regression between the germination percentage and the Falling Number of the wheat genotypes submitted to the pre-harvest sprouting.

The linear regression analysis conducted to study the grain characteristics elucidated a negative association between the percentage of germinated grains and the FN (Figure 1). Genotypes with a higher percentage of sprouted grains resulted in lower FN values. These results permit us to suggest that in those cases where the FN test cannot be performed, the germination percentage can be used as a selection tool for PHS. Even if the FN values and the grain germination percentage cannot be obtained, it is still possible to use the grain germination score, which has a high correlation $(\mathrm{r}=0.8899 * *)$ with the grain germination percentage. Our result revealed no association between the grain germination percentage and the hectoliter weight or the grain weight per spike (Table 2).

As per Brazilian norms for milling and other uses, a minimum value of FN (250 seconds) is required for the top wheat category (strong or high quality), 220 (seconds) for bread and domestic class, and 200 (seconds) for basic wheat (Brasil, 2010). Through linear regression analysis, it was possible to show that any germination percent or sprouting above $46 \%$ will lead to FN value below 200s. Sprouting scores between 32 and $46 \%$ were associated with FN values between 200 and 250s and all wheat samples with sprouting from 19 to $32 \%$ reached FN values between 250 and 300s. To reach FN values higher than $300 \mathrm{~s}$, the samples must not contain more than $19 \%$ of sprouted grains (Figure 1). These data suggest that the germination percentage accounts for $84 \%$ of the variation found in the falling number $\left(\mathrm{R}^{2}\right.$ $=0.8382$ ). It must be asserted that these values can only be used as a guideline to develop a selection criterion to discard the most susceptible lines representing lower FN, which can vary among locations and different crop cycles (Silva et al., 2019). The genotypes with a percent of germination above $46 \%$ (FN less than $200 \mathrm{~s}$ ), can be discarded at any stage of the selection. The lines with a percent of germination higher than $84 \%$ (corresponding to FN $<62$ s), even though with other useful characteristics, should be discarded at the beginning of the selection process or used in a hybridization program to improve their tolerance to PHS.

\section{Conclusions}

The grain germination percentage (sprouting) was more associated with the Falling Number (FN) than the visual sprouting score, the hectoliter weight and the grain weight per spike. Based on the grain germination percentage, the corresponding values of the FN (s) were calculated. A sample above $46 \%$ of the germinated grains would not reach the FN value of 200s. Values between 32 to $46 \%$ of germinated grains were associated with $\mathrm{FN}$ values between 200 and 250 s and from 19 to $32 \%$ of germinated grains with $\mathrm{FN}$ values of 250 to 300s. Samples with less than $19 \%$ germinated grains achieved FN values above 300s. This association between the grain germination percentage and the FN allows the wheat breeding programs to have a useful criterion for the selection, early discard of unsuitable lines and planning a new cycle of hybridization for resistance to PHS.

\section{Conflict of interest}

The authors declare that they have no conflict of interest 


\section{References}

AACC (2000) Approved methods of the American Association of Cereal Chemists, 10th ed, American Association of Cereal Chemists, St Paul, MN, USA.

Barbedo JGA, Guarienti EM, Tibola CS (2018) Detection of sprout damage in wheat kernels using NIR hyperspectral imaging. Biosystems Engeneering 175: 124-132.

Barnard A, Van Deventer CS, Maartens H (2005) Comparison between methods for estimating sprout damage in wheat. South African Journal of Plant and Soil 22(1):44-48.

Bassoi M, Flintham J (2005) Relationship between grain colour and preharvest sprouting-resistance in wheat. Pesquisa Agropecuária Brasileira 40:981-988.

Bassoi MC, Flintham J, Riede CR (2006) Analysis of pre harvest sprouting in three Brazilian wheat populations. Pesquisa Agropecuária Brasileira 41:583-590.

Brasil (2010) Ministério da Agricultura, Pecuária e Abastecimento. Instrução Normativa ${ }^{\circ} 38$, de 30 de novembro de 2010. Regulamento técnico do trigo. Diário Oficial da República Federativa do Brasil, Brasília, DF, n 229, Seção 1. Available at http://sistemasweb.agricultura.gov.br/sislegis/action/detalhaAto.do? method=visualizarAtoPortalMapa $\&$ chave $=358389789$, accessed on 14 February 2019.

Cruz CD (2006a) Programa Genes: análise multivariada e simulação. Cosme Damião Cruz. Viçosa: Ed. UFV, Pp.175.

Cruz CD (2006b) Programa Genes: estatística experimental e matrizes / Cosme Damião Cruz. Viçosa: Ed. UFV, Pp. 285.

Dencic S, Depauw R, Kobiljski B, Momcilovic V (2013) Hagberg Falling Number and Rheological Properties of Wheat Cultivars in Wet and Dry Pre harvest Periods. Plant Production Science 16(4):342- 351 .

DePauw RM, Knox RE, Singh AK, Fox SL, Humphreys DG, Hucl P (2012) Developing standardized methods for breeding preharvest sprouting resistant wheat, challenges and successes in Canadian wheat. Euphytica 188:7-14.

Dewey DR, Lu KH (1959) A correlation and path-coefficient analysis of components of crested wheatgrass seed production. Agronomy Journal 51(8):515-518.

Franco FA, PintoRB, Scapim CA, Schuster I, Predebon CT, Marchioro VS (2009) Tolerância à germinação na espiga em cultivares de trigo colhido na maturação fisiológica. Ciência Rural 39:2396-2401.
Gavazza MIA, Bassoi MC, Carvalho TC, Bespalhok Filho JC, Panobianco M (2012)Methods for assessment of pre-harvest sprouting in wheat cultivars. Pesquisa Agropecuária Brasileira 7:928-933

Hanft JM, Wych RD (1982) Visual indicators of physiological maturity in hard red spring wheat. Crop Science 22:584-587.

Humphreys DG, Noll J (2002) Methods for characterization of preharvest sprouting resistance in a wheat breeding program. Euphytica 126: 61-65.

MacMaster GJ, Derera NF (1976) Methodology and sample preparation when screening for sprouting damage in cereals. Cereal Research Communications 4:251-254.

Mares DJ, Mrva K (2008) Late-maturity alpha-amylase: low Falling Number in wheat in the absence of preharvest sprouting. Journal of Cereal Science 47:6-17.

Mares DJ, Mrva K (2014) Wheat grain preharvest sprouting and late maturity alpha amylase. Planta 240(6):1167-1178.

Nörnberg R, Luche H S, Groli EL, Danielowski R, Santos RL, Figueiredo RG, Silva JAG, Elias, MC, Maia LC, Oliveira AC (2015a) The search for productivity and pre-harvest sprouting tolerance in wheat. African Journal of Agricultural Research 10:1719-1727.

Nörnberg R, Silva JAG, Luche HS, Tessmann EW, Kavalco SAF, Zimmer CM (2015b) Tolerance to preharvest sprouting and yield of wheat genotypes from different breeding programs. Pesquisa Agropecuária Brasileira 50(8):698-706.

Nyachiro J M, Clarke F R, DePauw RE, Knox RE, Armstrong KC (2002) Temperature effects on seed germination and expression of seed dormancy in wheat. Euphytica 126:123-127.

Okuyama LA, Fonseca Junior NS, Caramori PH, Kohli MM (2018) Preharvest sprouting assessment in wheat genotypes influenced by temperature and degree days. Experimental Agriculture 54(4):483-490.

Paterson AH, Sorrells ME, ObendorfRL (1989) Methods of evaluation for preharvest sprouting resistance in wheat breeding programs. Canadian Journal of Plant Science 69:681-689.

Rakita SM, Torbica AM, Dokić LP, Tomić JM, Pojić MM, Hadnađev MS, Hadnađev TRD (2015) Alpha-amylase activity in wheat flour and breadmaking properties in relation to different climatic conditions. Food \& Feed Research 42(2):91-100.

Reddy LV, Metzger RJ, Ching M (1985) Effect of temperature on seed dormancy of wheat. Crop Science 25:455-259. 
SAS (Statistical Analysis System) (2001). Version 8.2.SAS Institute Inc., Cary, NC, USA.

Scheiner SM, Mitchell RJ, Callahan HS (2000) Using path analysis to measure natural selection. Journal of Evolutionary Biology $13: 423-433$

Shorter SC, Munro CA, Hodgkinson J (2005) Predicting preharvest sprouting susceptibility in New Zealand wheat cultivars. Euphytica 143: 309-312

Silva RR, Zucareli C, Fonseca ICB, Riede CR, Gazola D (2019) Nitrogen management, cultivars and growing environments on wheat grain quality. Revista Brasileira de Engenharia Agrícola e Ambiental, 23(11): 826-832.

Snedecor GW, Cochran WG (1982) Statistical methods. 7th edition, Ames: Iowa State University Press, Pp.507.

Steber CM (2016) Managing the Risk of Low Falling Numbers in
Wheat. USDA-ARS, and adjunct faculty, Dept. of Crop and Soil Science, Washington State University Pullman WA, 6p. Available at https://research.wsulibs.wsu.edu/xmlui/handle/2376/6373 acessed on 14 September 2020

Thomason W, Hughes KR, Griffey CA, Parrish DJ, Barbeau WE (2019) Understanding pre-harvest sprouting of wheat. Virginia Tech, Virginia State University, Publication 424-060, available at https://www.pubs.ext.vt.edu/424/424-060/424-060.html, accessed on 15 September 2020

Yanagisawa A, Nishimura T, Amano Y, Torada A, Shibata S (2005) Development of winter wheat with excellent resistance to pre-harvest sprouting and rain damage. Euphytica 143:313-318.

Zeeshan M, Arshad W, Khan MI, Ali S, Nawaz A, Batool A, Tariq M, Akram MI, Ali MA (2018) Breeding for pre-harvest sprouting resistance in bread wheat under rainfed conditions. Frontiers of Agricultural Science and Engineering 5(2): 253-261. 